\title{
ШЛЯХИ ПОКРАЩЕННЯ РОБОТИ ВИХОВАТЕЛЯ ГРУПИ ПРОДОВЖЕНОГО ДНЯ В УМОВАХ УПРОВАДЖЕННЯ НОВОГО ДЕРЖАВНОГО СТАНДАРТУ ПОЧАТКОВОЇ ЗАГАЛЬНОЇ ОСВІТИ
}

Кравцова I. А. Шляхи покращення роботи вихователя групи продовженого дня в умовах упровадження нового Державного стандарту початкової загальної освіти.

У статті розглянуто шляхи покращення організації роботи вихователя групи продовженого дня в умовах упровадження нового Державного стандарту початкової загальної освіти, вказано на роль педагогічної підтримки як основної форми індивідуалізації педагогічної взаємодії вихователя і вихованця у групі продовженого дня.

Ключові слова: вихователь ГПД, колектив групи, різновікові групи, педагогічна майстерність, педагогічна підтримка.

Кравцова И. А. Пути улучшения работы воспитателя группы продленного дня в условиях введения нового Государственного стандарта начального общего образования.

В статье рассмотрены пути улучшения организации работы воспитателя группы продленного дня в условиях введения нового Государственного стандарта начального общего образования, указана роль педагогической поддержки как основной формы индивидуализации педагогического взаимодействия воспитателя и воспитанника группы продленного дня.

Ключевые слова: воспитатель ГПД, коллектив группы, разновозрастные группы, педагогическое мастерство, педагогическая поддержка.

Kravtsova I. A. The Ways of Improving the Work of the After-School Program Teacher in Terms of the New Standard for Primary Education.

The article deals with the ways of improving the work of the after-school program teacher in terms of the new standard for primary education, proves the role of pedagogical support as amain form of the interaction between a teacher and a student of the after-school program.

Key words: the after-school program teacher, members of the group, different age groups, pedagogical mastership, pedagogical support.

Реалізація завдань нового Державного стандарту початкової загальної освіти передбачає розроблення цілісної системи роботи в групі продовженого дня, у якій створюються сприятливі умови для навчання i виховання, зміцнення здоров'я, розвитку пізнавальних інтересів та креативних здібностей молодших школярів.

Розвиток нації можливий лише за умови існування іiі освіченої, високодуховної, інтелігентної частини - професійного вчительства. Педагогічна майстерність - його кредо. Самореалізація особистості вчителя в педагогічній діяльності, що забезпечує саморозвиток учня, розглядається як вияв педагогом свого «Я» у професії, тобто його педагогічна майстерність. Втрата здатності регулювати педагогічний процес призводить до гальмування гармонійного розвитку взаємодії 3 учнями, i тоді 3'являється орієнтація лише на зовнішній контроль, а не самоконтроль, що впливає на органічність поведінки педагога [5, с. 48].

Виховати в педагога потребу професійного саморозвитку має допомогти система післядипломної освіти як органічна частина неперервної педагогічної освіти. На думку В. Бондаря, I. Жерносєка та М. Красовицького, провідним завданням системи післядипломної педагогічної освіти має бути стимулювання самоосвіти та саморозвитку 
вчителя. Важливо, щоб вона спрямовувалася на розвиток професіоналізму педагога щодореалізації компетентнісного підходу в організації навчально-виховного процесу [1, c. 190].

Аналіз психолого-педагогічної та методичної літератури (Н. Бібік, О. Овчарук, О. Пометун, О. Савченко та ін). надає змогу стверджувати, що у змісті педагогічноїосвіти з'явився новий стратегічний аспект - компетентнісний підхід, реалізація якого в системі післядипломної педагогічної освіти означає формування в учителів i вихователів взаємопов'язаних компетентностей - професійної, особистісної, соціальної, комунікативної тощо [6, с. 35].

Професійну компетентність вихователя ГПД щодо реалізації компетентнісного підходу в побудові навчально-виховного процесу розуміємо як здатність фахівця кваліфіковано й ефективно застосовувати теоретичні знання в запланованих i непередбачених педагогічних ситуаціях [4, с. 42].

Держава потребує активних i творчих спеціалістів, які, по-перше, мали б грунтовну теоретичну i практичну підготовку з обраного фаху, по-друге, могли самостійно приймати рішення, пов'язані 3 професійною діяльністю, а отже, створювати цінності власними силами. Тому одним із пріоритетних завдань сучасної школи є виховання відповідальної особистості, здатної до самоосвіти, саморозвитку, творчого застосування набутих знань.

На сучасному етапі реформування освіта потребує створення нової системи, що була б спрямована на формування освіченої творчої особистості, здатної до адаптації в соціумі, до розкриття своїх умінь і здібностей, до вміння задовольнити особистісні потреби.

Щоб виконати завдання, які постали перед школою, потрібно вдосконалювати навчально-виховний процес, розробляти нові методи і форми взаємодії вчителя та учнів, стимулювати самостійну навчальну діяльність вихованців, бо життя довело, що тільки ті знання, які людина здобула самостійно, стають її надбанням.

Виховання дитини - це важка і найбільш трудомістка сфера людської діяльності, успіх якої зумовлюється безліччю чинників найрізноманітнішого походження. У молодших школярів ще недостатньо розвинуті вміння самостійно мислити, цілеспрямовано використовувати навчальну літературу, працювати 3 нею, тобто в учнів не сформовані навички культури навчальної праці.

Усе більше батьків довіряють розвиток і реалізацію пізнавального та творчого потенціалу своєї дитини школі. I це закономірно. Напружений ритм життя потребує від дорослих повної реалізації та віддачі на роботі, більше часу батьки приділяють кар'єрному зростанню, і все менше часу від батьків отримує дитина. Але дорослі розуміють, що порожнину слід заповнювати, доки не спрацював негатив, і йдуть за допомогою до школи. Оскільки молодший шкільний вік є переломним у формуванні самостійності дитини, все частіше до школи приходять діти, які не мають достатніх навичок у самообслуговуванні. Одних одягали бабусі, іншим няні говорили, що і як робити, так би мовити «водили за ручку та годували з ложечки», третіх не привчили прибирати за собою. Можна побачити і дуже самостійних учнів, у яких сформовано почуття вседозволеності. Тому організація груп продовженого дня в школах $є$ однією 3 провідних форм виховання, навчання та відпочинку учнів.

Щороку все більше дітей відвідує групи продовженого дня. Отже, постає гостра потреба в організації, вдосконаленні, урізноманітненні діяльності цієї продуктивної форми навчання. Звісно, кожен вихователь ГПД має відповідну освіту, знає психологічні особливості учнів певного віку, володіє формами і методами роботи [2, 
с. 52]. Однак реалії сьогодення засвідчують необхідність постійного вдосконалення означених компетентностей педагогів.

Mema cmammi: визначити й обгрунтувати шляхи покращення роботи вихователя групи продовженого дня в умовах упровадження нового Державного стандарту початкової загальної школи.

Модернізація навчально-виховного процесу передбачає створення умов для реалізації кожним школярем власної освітньої траєкторії, визначеної його навчальними можливостями, запитами, інтересами, здібностями. У таких умовах актуалізується необхідність подолання традиційної суперечності навчання - між вимогами суспільства щодо рівня освіченості і вихованості підростаючого покоління та проблемами й інтересами самого учня. Власні проблеми та інтереси психологи розглядають як стимул, що спонукає людину до активної діяльності. Отже, стимулювання - це чинник дії вихователя. Але стимул лише тоді стає реальною, збуджувальною силою, коли перетворюється на мотив - внутрішній поштовх людини до діяльності. Причому цей внутрішній поштовх виникає не тільки під упливом зовнішніх стимулів, але й під упливом особистості самого школяра, його попереднього досвіду, потреб тощо.

Процес життєдіяльності школяра під час перебування у групі продовженого дня досить різноплановий. Його організовує вихователь таким чином, щоб кожна дитина була під наглядом, виконувала домашні завдання, навчалася засобів спілкування, отримувала постійну педагогічну і психологічну підтримку. Дитина має бути не лише школярем, а передусім - людиною 3 багатогранними інтересами, запитами, прагненням [7, с. 325].

Сучасні завдання освіти потребують від вихователя вмінь генерувати нові ідеї, креативно мислити, прагнень досягти якнайкращого результату, самовдосконалюватися, підвищувати фаховий рівень.

Відмінність колективу групи продовженого дня від звичайного класного колективу в тому, що він може бути різновіковим, тобто охоплювати учнів різних класів початкової школи. Складність полягає в організації самопідготовки, тому що вихователю необхідно порозумітися з учителями одразу кількох класів. Однак у різновіковій групі є й переваги: співпраця дітей різного віку дає змогу формувати в них навички взаємодії, вчить старших піклуватися про молодших.

Перевагою різновікових груп є й можливість реалізувати принцип наступності, що дає можливість комплексно розв'язувати пізнавальні, виховні та розвивальні завдання, адже кожна нижня ланка перспективно спрямована на вимоги наступної. Під час переходу однієї вікової ланки до іншої виникають психічні новоутворення, яких не було в попередньому віковому періоді [6, с. 42].

Структура навчальної діяльності виникає не одразу, а поступово: одні компоненти виникають раніше, інші - пізніше. Вони включаються в уже сформовану діяльність, утворюючи комбіновану форму - навчально-ігрову діяльність. У цей період важко переоцінити роль вихователя групи продовженого дня, адже безпосередньо під керівництвом вихователя в дитини формуються мотиви, під керівництвом дорослого вона вчиться ставити собі завдання, дорослий показує способи розв'язування поставлених завдань, i насамкінець, навчає дитину оцінювати продукт власної діяльності. Водночас у групі продовженого дня триває формування навичок із дотримання режиму дня, правил особистої гігієни, ціннісних орієнтацій дитини [5, с. 48].

Невід'ємним складником функціонування будь-якого колективу, зокрема групи продовженого дня, є дотримання правил поведінки під час сумісної діяльності. Завданнямпочаткової школи є допомога учням у самовираженні, вияві ініціативи 
розвитку самостійності й творчого потенціалу. Усього цього більшість учнів не можуть робити вдома $з$ різних причин: не мають братів і сестер, а навчаються в класі, де діти одного віку.

Не менш важливим для дітей 6-10 років $є$ рівень вольової та соціальної зрілості, що виявляється в засвоєнні норм спілкування, правил поведінки в різних ситуаціях і вмінні їм підкорятися, свідомій регуляції поведінки, вмінні співпрацювати до сприйняття ціннісних орієнтацій сучасності, які слід формувати під час годин відпочинку цілеспрямовано та під час режимних моментів опосередковано.

Одним із важливих моментів у становленні особистості молодшого школяра $є$ формування адекватної самооцінки. Під час знаходження дитини в групі продовженого дня відбувається зміна колективу, видів діяльності, викладача. Залежно від рис характеру, темпераменту та розвитку соціально-комунікативних навичок учні по-різному беруть участь у навчально-виховному процесі. Адекватна самооцінка дитини сприяє органічному включенню в колектив і самореалізації [4, с. 43].

Отже, якщо поставитися творчо до вироблення правил поведінки ГПД з точки зору вихователя, то можна отримати певний бонус - свідоме дотримання дисципліни школярами, перші кроки формування навичок групової діяльності та налагодження взаємин «учень - учень», «учень -учитель». Ця форма роботи може бути використана для будь-яких паралелей. Діти як шести, так і десяти років із задоволенням візьмуть участь у виробленні правил поведінки.

Вихователеві слід пам'ятати, що допомога учням має бути завжди своєчасною, оскільки надто рання допомога розслабляє учня, його волю, а запізніла призводить до зайвої втрати часу, зменшує інтерес до виконання роботи. Головне - така допомога має сприяти засвоєнню програмового матеріалу, розширювати можливості учнів самостійно міркувати, пробуджувати творчу ініціативу, активність.

Використовуючи різнорівневі завдання, враховуючи індивідуальні особливості учнів, забезпечуючи свободу вибору ними самостійних робіт, різних за характером та рівнем складності, вихователь стимулює зацікавлене ставлення дітей різновікової групи до навчання, створює ситуацію успіху.

Працюючи планомірно і розважливо, продумано використовуючи знання про вікові особливості дітей молодшого шкільного віку, вихователь групи продовженого дня не тільки оптимально налагодить навчальну та виховну діяльність, а й отримуватиме задоволення від власної роботи.

Об'єднуючи молодших школярів у другій половині дня в єдиний колектив, вихователь реалізує педагогічну майстерність за умови правильної організації педагогічної взаємодії учасників навчально-виховного процесу. А однією з основних форм індивідуалізації педагогічної взаємодії вихователя i вихованця в групі продовженого дня є педагогічна підтримка.

Для успішного здійснення педагогічної підтримки вихователь повинен дотримуватись певних норм:

- любов до дитини і повне сприймання її як особистості;

- перевага діалогових форм спілкування з дітьми;

- розуміння інтересів кожної дитини;

- очікування успіху в розв'язанні проблеми;

- визнання права на свободу вибору;

- заохочення та схвалення самостійності;

- уміння бути дитині товаришем;

- власний самоаналіз, постійний самоконтроль. 
Якщо вихователь групи продовженого дня любить дітей та свою справу, творчо ставиться до роботи, ним створено затишний кабінет- це сприятиме якісному результату співпраці. А якщо дитина має піднесений настрій, відчуває підтримку й отримує високу оцінку своєї роботи, результативність іiі діяльності автоматично підвищується. Логічно передбачити і задоволення учнів від перебування у групі продовженого дня, оскільки у вихованні все має грунтуватися на особистості педагога. Будь-яка програма викладання чи метод виховання, хоч би якими добрими вони не були, не перейшовши в переконання вихователя, залишаються мертвими, такими, що не мають ніякої сили в дійсності [3, с. 43].

К. Ушинський зауважував, що «найпильніший контроль у цій справі не допоможе. Вихователь ніколи не може бути сліпим виконавцем інструкції. Немає сумніву, що багато чого залежить від загального розпорядку в закладі, але найголовніше завжди залежить від особи вихователя, що стоїть віч-на-віч із вихованцем» [8, с. 137].

Переконані, що вплив особистості педагога на молоду душу становить ту виховну силу, якої не можна замінити на підручники ні моральними сентенціями, ні системою покарань і заохочень, оскільки дух закладу живе не в стінах, не на папері, а в характері більшості вихователів і звідти вже переходить у характер вихованців.

\section{Література}

1. Жерносек И. Ф. Повышение квалификации педагогических кадров / И. Ф. Жерносек // Под. ред. И. Ф. Жерносека, М. Ю. Красовицького, С. В. Крисюка. К. : Вища школа, 1992. - 190 с.2. Кочерга О. Розвиток психологічної компетентності вчителя початкової школи / Олександр Кочерга // Рідна школа. - 2013. - № 11. - С. 52 53. 3. Мельничук С. К. Д. Ушинський про педагогічну підготовку вчителя початкових класів / С. Мельничук // Початкова школа. - 2013. - № 1. - С. 43-44. 4. Митник О. Психолого-педагогічні засади підготовки вчителя у системі післядипломної освіти до реалізації компетентнісного підходу/ Олександр Митник// Рідна школа. - 2013. № 11. - С. 42-44. 5. Моделирование педагогических ситуаций / под. ред. Ю. Н. Кулюткина, Г. С. Сухогубской. - М. : Просвещение, 1981. - 148 с. 6. Савченко О. Я. Уміння вчитися як ключова компетентність загальної середньої освіти / О. Я. Савченко // Компетентнісний підхід у сучасній освіті: світовий досвід та українські перспективи / за заг. ред. О. В. Овчарук. - К. : К.І.С., 2004. - С. 34-46. 7. Сухомлинський В. О. Три елементи школи / В. О. Сухомлинський. - К. : Акта, 2012. - 537 с. 8. Ушинський К. Д. Твори / К. Д. Ушинський. - К. : Рідна школа. -1954. - 368 с.

УДК 371.3:330

Юлія Люлькова

\section{ЕКОНОМІЧНІ ЗНАННЯ У ЗМІСТІ ГЕОГРАФІЧНОЇ Й ЕКОНОМІЧНОЇ ШКІЛЬНОЇ ОСВІТИ}

Люлькова Ю. М. Економічні знання у змісті географічної й економічної шкільної освіти.

У статті визначено місце економічних знань у змісті географічної й економічної шкільної освіти. 3'ясовано, що економічні знання варто розуміти як систему уявлень, понять i термінів, фактів, відображення закономірностей, законів i теорій, світоглядних ідей, що формують ставлення особистості до різних явищ соціальноекономічного й суспільного життя.

Ключові слова: економічні знання, шкільний курс географії, шкільний курс економіки, освітня компетенція, економічна компетентність, географічна компетентність. 